原著

\title{
Catecholamineの血液凝固線溶能に及ぼす
} 効果にかんする研究

\author{
札幌医科大学内科学第二講座 (主任 宮原光夫教授) \\ 羽田 靖子 \\ 札幌医科大学中央検查部, 内科学第二講座 \\ 黒川 一郎

\section{STUDIES ON THE EFFECT OF CATECHOLAMINE UPON BLOOD COAGULATION AND FIBRINOLYSIS} \\ Yasuko Haneda \\ The Second Department of Internal Medicine, Sapporo Medical College \\ (Chief: Prof. M. Miyahara) \\ Ichiro Kurokawa \\ Central Clinical Laboratory, The Second Department of Internal \\ Medicine, Sapporo Medical College
}

\begin{abstract}
概要 虚血性心疾患の発生もしくは促進因子としてのcatecholamine（CA）の作用を，その血液凝固 線溶能に及ぼす影響から検討すべ，生理的微量のnoradrenalineおよびadrenaline負荷，ならびに運 動負荷に和ける血液凝固線溶能につき系統的に検討した。 またC Aの血液凝固線溶无進作用に対する 機序の一部を解明する目的で，交感神経受容体㳯断薬を用いて C Aへの影響をin vivo, in vitroで検 討した．その結果，CAKより血液凝固能は九進し，線溶能む同様に九進をみた。しかしてCAは主 として栓球と第XI因子への直接作用を介して凝固充進作用をるたらするのであることが結論つけりれ た. そして $\alpha$ なら゙に $\beta$ 遮断薬はいずれる C Aのかかる作用を㧕制することを明らかにした。
\end{abstract}

\section{I. 緒 言}

㹟心症，心筋硬塞発作時にcatecholamine（以 下C A）の分泌が増加することはよく知られてい るが，逆に生理的な分泌九進が発作誘発の一因子 である可能性は強い，他方，虚血性心疾患患者 では血液凝固能の亢進している場合が多いといわ れ, さらにC AKよつて栓球数, 凝集粘着能の增 加，全血凝固時間，prothrombin時間の短縮，第 $\mathrm{V}$, VIII⿴囗大因子活性の増加, あるいは線溶能の元進

〔昭和 48 年 5 月 4 日受稿〕
をみる等の報告に接する、しかしながら，これ等 の報告はいずれも C A と虚血性心疾患の発生因と の関連の有無を検討したものではないそそのため もあって，実験に用いたC A量も多くは生体内の CA濃度を考慮したものとは言い難く，投与方法 あまらまらである。ささらにまたC Aの作用を同時 に多数の㠜固線溶因子については検索した報告に は殆ど接しない。

そこで著者らはC A の分必一血液凝固能九進の 一連の過程と狭心症や心筋硬塞発作の成因との関 連をみるべく，運動時や狄心症発作時にみられた 
のとほぼ等しいC A 血中レベル2゙になるようにC $\mathrm{A}$ を負荷して，凝固線溶因子への影響をみた。さ らにMaster二階段二重運動負荷を施行し，その前 後で同様の検討を行なつた. 他方，これらin vivo の実験では, C A の凝固線溶因子に対する直接作 用の他に，血行動態や代謝面への影響を介する間 接作用も同時に含まれる可能性も否定できない. そこでC Aの直接効果をみるべく, in vitroで血 液にC Aを添加し同様の実験を行なつた。ささら K，栓球数の増加が C A $\alpha \alpha$ 作用による ${ }^{3)}$ ，また 第V四因子，線溶能が $\beta$ 作用に依存する(2) 6)などの 報告がみられる。このようにC A の作用機序を分 析するのに，受容体との関連を検討することは有 用と思われるので, in vivo, in vitroで交感神経受 容体遮断薬 (以下遮断薬) 用いてC Aの作用 の影響をみた．以上の実験に和いて若干の知見を 得たので，その成績を述べ考察を加光たい．

\section{II. 対象および方法}

1） C A 負荷による血液凝固線溶能の影響.

当科入院. 一部は外来患者のうち, 血液凝固学 的異常のない，男59，女10，計69例（年令20〜 76才）を対象とした。 まず卧位安静を 30分保た せた後, 在来当教室で行なわれている方法 ${ }^{2} に$ 従つてCA負荷を行なつた。すなわち，運動負 荷あるいは狭心症発作時のCA血中レベルにほ ぼ等しくなるように，noradrenaline (以下NA), adrenaline（以下A）をそれぞれ別に $0.2 ， 0.1$ $\mu \mathrm{g} / \mathrm{kg} / \min 10$ 分間点滴静注し，点滴前と終了直前 で採血した。

2）運動負荷の血液凝固線溶能に及ぼす影響.

1）と同樣に患者を選定し，男20，女 7 , 計27例 （年令30〜70才）を対象として，Masterの二階段 二重運動負荷を行ない, その直前および終了直後 に採血した。

以上in vivoでのC A 扎よび運動負荷実験で採 血後検討した凝固線溶因子执よび測定法は，(1) 栓球数；Brecher-Cronkite変法 (1968), (2) 栓球 粘着率；田中法(1957), (3) prothrombin time (PT); Quick一段法, (4) partial thrombopl- astin time (PTT), (5) 第II 因子; Owren法 (1951)，(6) 第V因子；萩原法(1957)，(7) 第 （VII+X）因子； Hougie法 (1959), (8) 第VIII 因子；松岡法(1961)，(9) 第 (XII+XI) 因子; 松岡法(1962), (10) 血将因子; Biggs and Douglas法 (1953), (11) 血清因子; Biggs and Douglas 法 (1953), (12) Euglobulin溶解時間（E L T); 風間法 (1966), (13) Fibrinogen 量 ; Tyrosine法（1965）である.なおこれらのうら， 血浆拉よび血清因子はそれぞれ吸着血浆を20倍， 血清を40倍希釈にして用いた.

3）ＣAならびにこれに対する遮断薬の影響.

C Aの血液凝固線溶能に及注寸变化とこれに遮 断薬が如何なる影響を及ぼすが検討すべく，年 令19〜23才の健康男子 8 例を対象として次の如き 実験を行なつた。な就 C A としてはAを，遮断薬 は $\alpha$ 遮断薬のphentolamine（以下 P A） と $\beta$ 遮断 薬のpropranolol (以下Prop) を用いた。

まずin vivoの実験では，8例について以下の 順で検索した．すなわち対照としてのA単独負荷 実験は，卧位安静 30 分後第 1 回，ついで生食 1 $\mathrm{ml} / \mathrm{min} 10$ 分間点滴後に第 2 回, 生食に加えて A $0.1 \mu \mathrm{g} / \mathrm{kg} / \mathrm{min}$ 点滴10分後に第 3 回目の採血を行 なつた．遮断薬の効果についての検討は，第 1 回は無処置採血，a） P A $1.5 \mathrm{mg} / \min 10 \sim 15$ 分 間点滴後に第 2 回，ついで P AK加えてA 0.1 $\mu \mathrm{g} / \mathrm{kg} / \mathrm{min}$ 点滴 10 分後に第 3 回目の，またb)

Prop $1 \mathrm{mg} / \mathrm{min} 10$ 分間静注後飞第 2 回, ついでA $0.1 \mu \mathrm{g} / \mathrm{kg} / \mathrm{min}$ 点滴10分後に第 3 回目の採血を行 なつた.なおこの同一人についての3 回の実験は 少なくとも1週間の間隔を执いて実施した. 負荷 したPA抹よびPropは，従来より当教室で使用し ている量で，Aに十分拮抗することが明らかにさ れている量に活ぽ一致する.

In vitroの 実験では 5 例につき, $37^{\circ} \mathrm{C}$ 温度下 でまず抗凝固㭗添加全血, 栓球欠乏血浆 (以下 $P$ P P) もしくは栓球豊富血浆（以下 P R P) K, Aを 5 または $10 \mu \mathrm{g} / \mathrm{ml}$ 添加して凝固線溶因子を測

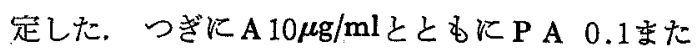


は $0.5 \mathrm{mg} / \mathrm{ml}$, Prop 0.1 たは $0.5 \mathrm{mg} / \mathrm{ml}$ 添加時, さらに别個にP A あるいはProp $0.5 \mathrm{mg} / \mathrm{ml}$ それぞ れ単独添加時について同様の検討を行なつた，血 液は $3.8 \%$ クエン酸ソーダ 1 : 血液 9 の割合にン リコン注射器で採血したものを用い，P P Pは採 血後 3,000rpmで 5 分間, P R P は 1,000rpmで 10分間遠心しその上清を採取し，A と遮断薬は心 ロナール生食緩衝液に溶解したもの（pH約 7.4） を用い，添加10分後に諸因子を測定した。

以上の遮断薬の実験で検討した凝固線溶因子お よび測定法は，(1) 栓球数；Brecher-Cronkite変 法 (1968), (2) 栓球粘着率 ; 田中法 (1957), (3) 栓球第 3 因子; Hardisty and Hutton法 (1966), (4) 第VIII因子; 松岡法 (1961), (5) 第 (XII+ XI）因子；松岡法（1962），(6) 線溶能； Fibrin加熱平板法（1966）である. これらのらち栓 球数, 栓球粘着率は抗㠜固薬添加全血, 栓球第 3 因子は P R P，第VIII，（XII+XI）因子, 線溶能は P P Pを用いた.

\section{III. 成 績}

1）In vivoでのC A 負荷による影響 (Table 1)

(1) N A 負荷: 栓球数, 栓球粘着率の増加, P T ， P T T, 第 II， V，VII因子，血浆ならびに 血清因子，E L T 和のおのの活性上昇または時間 短縮はすべて $5 \% ， 1 \%$ たは $0.1 \%$ 以下の危険 率で有意であつた。 これに対して第 $(\mathrm{VII}+\mathrm{X})$,

（XII+XI）因子, fibrinogen量はいずれも明·らか な変化を示さなかつた。

(2) A 負荷：栓球数, 栓球粘着率の增加, $\mathrm{P}$ T T，第 II，VII，（XII+XI）因子，血浆因子， E L T の活性上昇または時間短縮はすべて $5 \%$ ， 1\%または $0.1 \%$ 以下の危險率で有意であり，P $\mathrm{T}$ ，第 V因子，血清因子はすべて活性上昇傾向を 示したが有意ではない，また第（VII+X）因子と fibrinogen量は著変なかつた。

2）運動負荷による影響（Table 2)

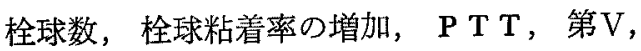
VIII，（XII＋XI）因子，血浆因子，E L T 初の括の
Table 1. Changes in blood coagulation and fibrinolysis following catecholamines administration. (Mean士S.E.) noradrenaline; $0.2 \mu \mathrm{g} / \mathrm{kg} / \mathrm{min}$. adrenaline; 0.1 $\mu \mathrm{g} / \mathrm{kg} / \mathrm{min}$.

\begin{tabular}{|c|c|c|c|c|}
\hline & \multicolumn{2}{|c|}{ Meradrenaline } & \multicolumn{2}{|c|}{ Adrenal ine } \\
\hline & before & after & beforat & after \\
\hline Piatelot Count $\times 10,0 \mathrm{man}$ & $19.7 \pm 0.98$ & $24.7 \pm 1.34$ & $19.1 \leqslant 1.13$ & 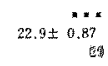 \\
\hline Platelet Athesiventess $\quad \theta_{i}$ & $10.5 \pm 1.63$ & $17.6 \pm 1.94$ & $14.7 \pm 1.69$ & $20.8 \pm 2.12$ \\
\hline$P \quad T$ & $113.7 \pm 5.95$ & $\begin{array}{r}122.2 \pm 6.45^{\circ} \\
\mathrm{eQ}\end{array}$ & $134.7 \pm 7.33$ & $\begin{array}{r}141.6 \pm 6.06 \\
0 \%\end{array}$ \\
\hline $\begin{array}{lll}P & T & T\end{array}$ & $60.9+3.44$ & $\begin{array}{r}55.6 \pm 2.92 \\
054\end{array}$ & $64.2 \pm 4.24$ & $59.1 \pm 3.44$ \\
\hline Factor il & $143.1 \pm 14.25$ & 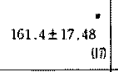 & $193.7 \pm 10.34$ & $161.8 \pm 11.54$ \\
\hline Factor V & $125.7 \pm 9.61$ & $\begin{array}{r}167.3 \pm 12.84 \\
415\end{array}$ & $107.7 \pm 11.08$ & $122.9 \pm 10.94$ \\
\hline Fuetor $(n+1)+x)$ & $101.8 \pm 7.15$ & $\begin{array}{r}105.2 \pm 7.92 \\
03\end{array}$ & $96.7 \pm 7.39$ & $\begin{array}{r}96.8 \pm 8.76 \\
09\end{array}$ \\
\hline Factor itl & $103.7 \pm 8.19$ & $131.3 \pm 12.71$ & $115.7 \pm 8.60$ & $\begin{array}{r}* * * \\
256.9 \pm 11.31 \\
\end{array}$ \\
\hline Factor $(\mathrm{g} a+\mathrm{X})$ & $108.9 \pm 11.19$ & $\begin{array}{r}110.8 \pm 7.40 \\
118\end{array}$ & $132.3 \pm 13.28$ & $185.2 \pm 17.14$ \\
\hline Plasma Factor & $141.7 \pm 13.89$ & $\begin{array}{r}-1 . \\
202.7 \pm 19.45 \\
201 \\
\end{array}$ & $117.3 \pm 10.46$ & $138.3 \pm 10.05$ \\
\hline Sertam Factor & $103.1 \pm 8.84$ & $143.5 \pm 17.51^{\circ}$ & $108.4 \pm 12.61$ & $115.3 \pm 8.24$ \\
\hline Euglobulin Lysis Time & $413.6 \pm 54.07$ & $324.5 \pm 66.14$ & $372.9 \pm 34,17$ & $\begin{array}{r}298.6 \pm 43,68 \\
\text { (II) }\end{array}$ \\
\hline Fibrinogen & $396.4 \pm 34.65$ & $390.4 \pm 29.33$ & $385.1 \pm 14.32$ & $387.4 \pm 19.37$ \\
\hline
\end{tabular}

の活性上昇または時間短縮はすべて $5 \% ， 1 \%$ 年 たは 0.1\%以下の危険率で有意であった。他方， 第 II，（VII+X）因子, 血清因子は軽度の上昇を 示したが, PT, fibrinogen量は殆ど変化しなかっ た.

3） C Aならびにこれに対する遮断薬の影響.

(1) In vivoの実験 (Table 3)

A 単独負荷を行なつた実験（Table 3ー1）で は，いずれも栓球第 3 因子を除いては生食負荷後 に大きな変化はみられなからたが，A 負荷後に第 (XII+XI)因子, 線溶能が $0.1 \%$, 栓球数，栓球粘 着率，第V业因子が $1 \%$ 以下の危険率でいずれも有 
Table 2. Changes in blood coagulation and fibrinolysis immediately after Master's double two step exercise. (Mean土S.E.)

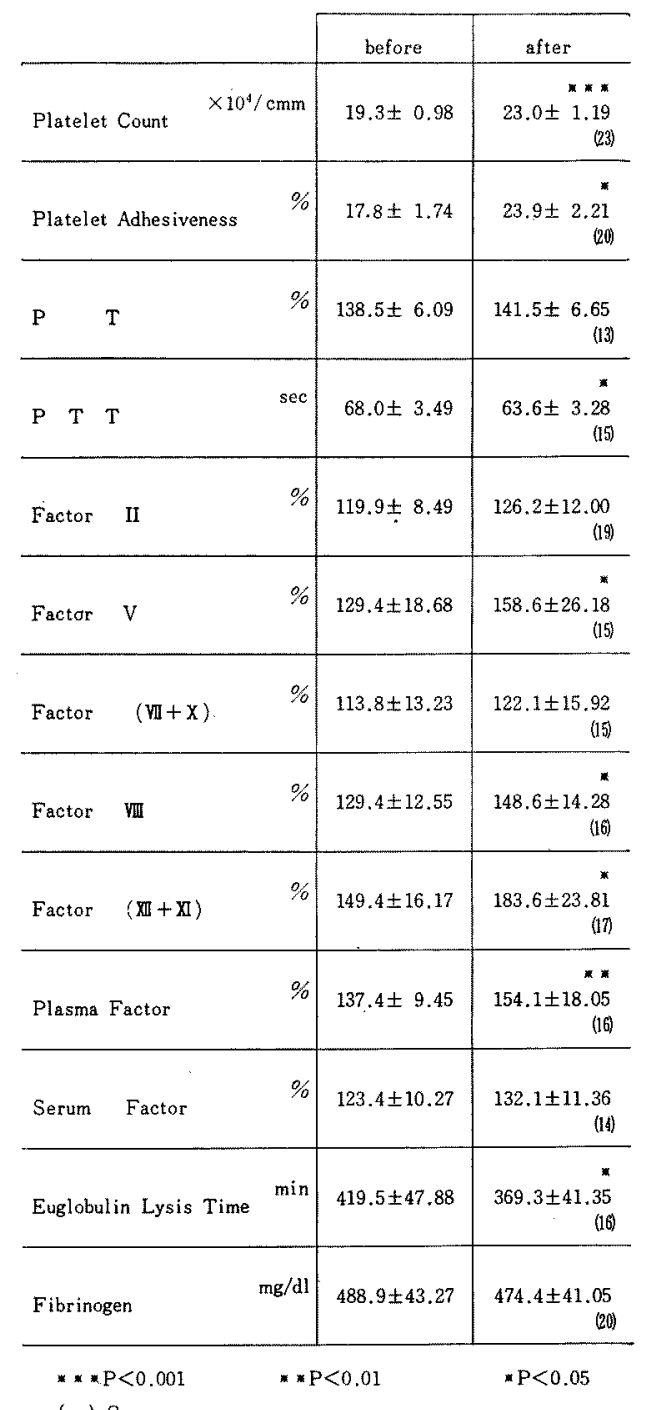

意に增加，栓球第 3 因子は有意ではないが前值に 比し平均 $41.4 \%$ 上昇した.

P A 負荷後 P A と共にAを投与した実験(Table $3-2)$ では，P A 単独投与後に栓球第 3 囚子の みは有意 $(\mathrm{P}<0.001)$ に低下したが他の因子に は著変がなかつた。つぎに $\mathrm{P} \mathrm{A}+\mathrm{A}$ 投与では，A
単独で有意に増加した栓球数, 栓球粘着率, 拉よ び有意ではないが強い上昇を示した栓球第 3 因子 はいずれも増加せず，平均值ではむしる減少し た．他方第怔因子の活性上昇も明らかな抑制㑯向 を示し，また前值に比して第 $(\mathrm{XII}+\mathrm{XI})$ 因子は逆 に有意 $(P<0.05)$ ，線溶能は有意ではないが 低下した。

Prop投与後A投与を行なつた実験（Table 3ー 3）では，まずrop前投与後，栓球数の増加，栓 球粘着率と栓球第 3 因子の低下がともに有意（P く0.05）であるが，他は大差なかつた.つぎに A による変化では，栓球数は $\mathrm{A}$ 単独時と同様で有意 $（ \mathrm{P}<0.05 ）$ の增加を示した。他方 $\mathrm{A}$ 単独で有意 に増加した栓球粘着率，第 $(\mathrm{XII}+\mathrm{XI})$ 因子, 線溶 能はとすに逆に有意 $(P<0.05)$ に低下した。 た栓球第 3 因子も有意ではないが低下し，第证因 子は軽度上昇するるA単独時にみられたような有 意な上昇は示さなかった。

(2) In vitroの実験（Table 4 特よび5)

Table 4 に示す如く, A $5 \mu \mathrm{g} / \mathrm{ml}$ 添加では栓球数 の減少, 栓球粘着率, 栓球第 3 因子, 第 VIII, (XII +XI）因子の上昇はとるに軽度で，線溶能のみが

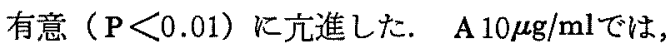
栓球数の減少, 栓球粘着率, 第 (XII+XI) 因子の 上昇か $5 \%$ ，栓球第 3 因子，線溶能の上昇が 1 \%以下の危険率でそれぞれ有意であり，第俨因子 は有意ではないが，平均 $27.8 \%$ の昇を示した. すなわち $\mathrm{A} 10 \mu \mathrm{g} / \mathrm{ml}$ の方が $5 \mu \mathrm{g} / \mathrm{ml}$ よりその効果 が顕著なので, 以下の実験では $10 \mu \mathrm{g} / \mathrm{ml}$ 用いた。

つぎに A $10 \mu \mathrm{g} / \mathrm{ml}$ と P A $0.1 \mathrm{mg} / \mathrm{ml}$ を同時に添 加すると， $\mathrm{A}$ 単独時に 比し栓球数は有意 $(\mathrm{P}<$ 0.05） 飞増加し，栓球粘着率，第（XII+XI）因子 は $1 \%$ ，第证因子は $5 \%$ 以下の危険率で有意低 下した。，一方栓球第 3 因子，線溶能は有意ではな いが，いずれも低下した，PAを $0.5 \mathrm{mg} / \mathrm{ml}$ に増 量すると，A単独時に比し栓球数の増加，他の諸 因子の低下はいずれも5\%または1\%以下の危险 率で有意であつた.

A $10 \mu \mathrm{g} / \mathrm{ml}$ ，Prop 0.1mg/ml添加では，A単独 
Table 3. Influence of phentolamine and propranolol upon effect of adrenaline on blood coagulation and fibrinolysis in vivo. (Mean \pm S.E.)

adrenaline; $0.1 \mu \mathrm{g} / \mathrm{kg} / \mathrm{min}$. phentolamine; $1.5 \mathrm{mg} / \mathrm{min}$. propranolol; $1 \mathrm{mg} / \mathrm{min}$.

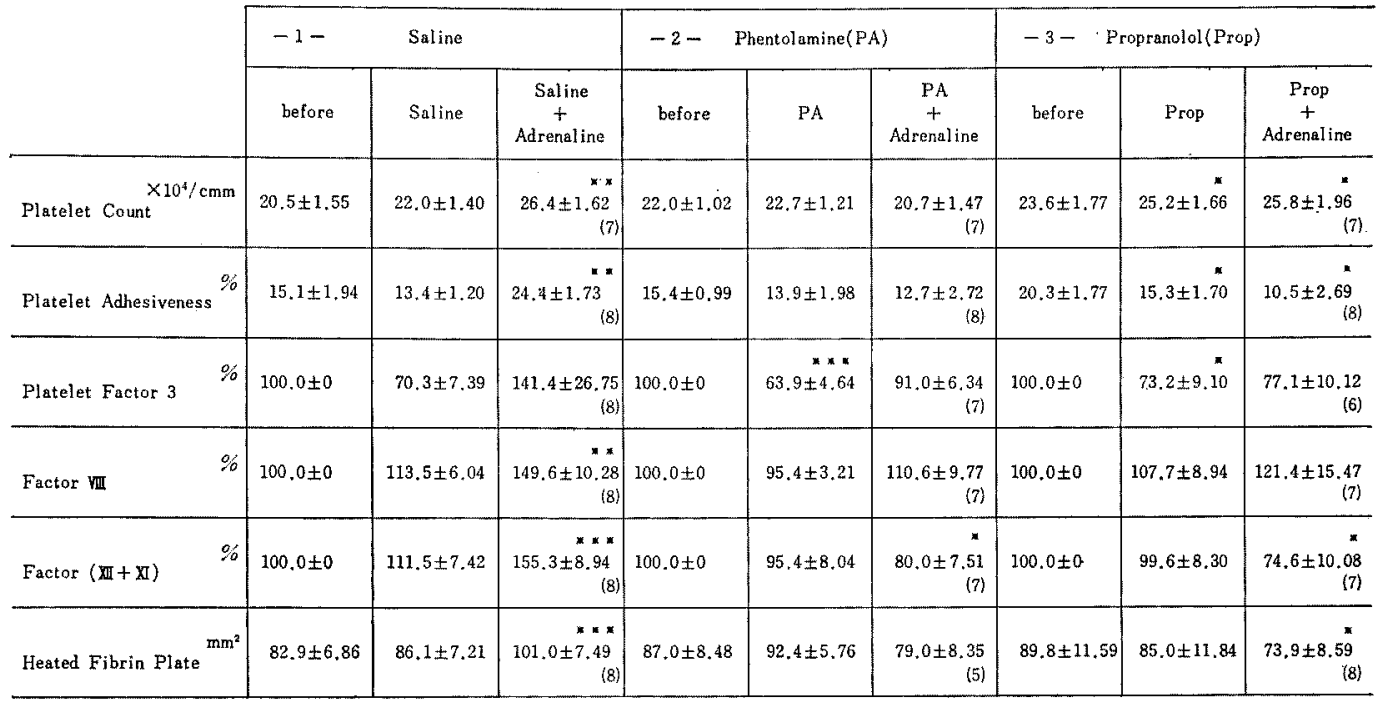

$\ldots \mathrm{p}<0.001 \quad \ldots \mathrm{p}<0.01 \quad * \mathrm{p}<0.05 \quad($ ) Cases

Table 4. Effect of adrenaline upon blood coagulation and fibrinolysis in vitro. (Mean士S.E.)

\begin{tabular}{|c|c|c|c|}
\hline & \multicolumn{3}{|c|}{ Adrenaline $(\mu \mathrm{g} / \mathrm{ml})$} \\
\hline & 0 & 5 & 10 \\
\hline Platelet Count $\times 10 \% \mathrm{cmm}$ & $22.4 \pm 2.32$ & $20.4 \pm 1.52$ & $19.4 \pm 1.65$ \\
\hline Platelet Adhesiveness & $19.4 \pm 3.17$ & $22.6 \pm 1.96$ & $26.1 \pm 1.61$ \\
\hline Platelet Factor 3 & $100.0 \pm 0$ & $124.2 \pm 9.96$ & $188.4 \pm 25.45$ \\
\hline Factor VIII & $100.0 \pm 0$ & $115.0 \pm 11.52$ & $127.8 \pm 11.65$ \\
\hline Factor $(\mathbf{X I}+\mathbf{X I})$ & $100.0 \pm 0$ & $171.0 \pm 28.53$ & $200.0 \pm 25.38$ \\
\hline Heated Fibrin Plate $\quad \mathbf{m m}^{2}$ & $95.4 \pm 14.73$ & $111.8 \pm 17.28$ & $130.0 \pm 21.43$ \\
\hline
\end{tabular}


Table 5. Influence of phentolamine and propranolol upon effect of adrenaline on blood coagulation and fibrinolysis in vitro. ( 5 cases, Mean士S.E.)

\begin{tabular}{|c|c|c|c|c|c|}
\hline & \multirow{3}{*}{$\begin{array}{l}\text { Adrenaline } \\
10 \mu \mathrm{g} / \mathrm{ml}\end{array}$} & \multicolumn{4}{|c|}{ Adrenaline $10 \mu \mathrm{g} / \mathrm{ml}$} \\
\hline & & \multicolumn{2}{|c|}{ Phentolamine $(\mathrm{mg} / \mathrm{ml})$} & \multicolumn{2}{|c|}{ Propranolol (mg/ml) } \\
\hline & & 0.1 & 0.5 & 0.1 & 0.5 \\
\hline$\times 10^{4} / \mathrm{cmm}$ & & * & $\cdots$ & & - \\
\hline Platelet Count & $19.4 \pm 1.65$ & $25.9 \pm 3.21$ & $29.5 \pm 2.86$ & $21.9 \pm 2.63$ & $28.5 \pm 4.06$ \\
\hline$"$ & & $m \approx$ & 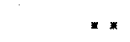 & 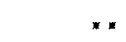 & $m$ \\
\hline Platelet Adhesiveness & $26.1 \pm 1,61$ & $15.5 \pm 2.23$ & $7.9 \pm 1.70$ & $13.9 \pm 2.28$ & $8.0 \pm 1.52$ \\
\hline Platelet Factor 3 & $188.4 \pm 25.45$ & $143.6 \pm 21.56$ & .* & $158.8 \pm 39.46$ & $163.8 \pm 45.98$ \\
\hline$\%$ & & * & $*$ & & . \\
\hline Factor VIII & $127.8 \pm 11.65$ & $106.2 \pm 9.69$ & $89.2 \pm 10.22$ & $116.2 \pm 10.71$ & $95.2 \pm 11.74$ \\
\hline$\%$ & & $* *$ & $* *$ & * & $\approx *$ \\
\hline Factor $(x]+X I)$ & $200.0 \pm 25.38$ & $145.4 \pm 25.94$ & $117.8 \pm 17.50$ & $159.6 \pm 32.10$ & $135.4 \pm 22.95$ \\
\hline $\mathrm{mm}^{2}$ & & & $*$ & * & $n$ \\
\hline Heated Fibrin Plate & $130.0 \pm 21.43$ & $98.0 \pm 13.84$ & $71.4 \pm 5.85$ & $98.0 \pm 13.88$ & $83.8 \pm 12.19$ \\
\hline
\end{tabular}

Table 6. Effect of phentolamine and propranolol upon blood coagulation and fibrinolysis in vitro. phentolamine; $0.5 \mathrm{mg} / \mathrm{ml}$. propranolol; $0.5 \mathrm{mg} / \mathrm{ml}$.

\begin{tabular}{|c|c|c|c|c|}
\hline & \multicolumn{2}{|c|}{ Phentolamine } & \multicolumn{2}{|c|}{ Propranolol } \\
\hline & before & after & before & after \\
\hline$\times 10^{4} / \mathrm{cmm}$ & $19.7 \pm 3.5$ & $\begin{array}{r}23.4 \pm 5.1 \\
(5)\end{array}$ & $19.7 \pm 3.5$ & $\begin{array}{r}* \\
21.8 \pm 3.8 \\
(5)\end{array}$ \\
\hline Platelet Adhesiveness & $12.6 \pm 3.0$ & $6.2 \pm \begin{array}{r}* \\
2.1 \\
(5)\end{array}$ & $12.6 \pm 3.0$ & $\begin{array}{r}11.6 \pm 1.9 \\
(5)\end{array}$ \\
\hline Platelet Factor 3 & $100.0 \pm 0$ & $\begin{array}{r}98.7 \pm 6.6 \\
(6)\end{array}$ & $100.0 \pm 0$ & $\begin{array}{r}117.3 \pm 10.1 \\
(6)\end{array}$ \\
\hline Factor VIII & $100.0 \pm 0$ & $\begin{array}{r}92.7 \pm 10.6 \\
(6)\end{array}$ & $100.0 \pm 0$ & $\begin{array}{r}93.0 \pm 8.1 \\
(5)\end{array}$ \\
\hline Factor. $(\mathrm{XI}+\mathrm{XI})$ & $100.0 \pm 0$ & $\begin{array}{r}103.8+7.9 \\
(6)\end{array}$ & $100.0 \pm 0$ & $\begin{array}{r}110.0 \pm 9.4 \\
(5)\end{array}$ \\
\hline Heated Fibrin Plate & $72.0 \pm 7.0$ & $\begin{array}{r}57.8 \pm 3.7 \\
(6)\end{array}$ & $76.8 \pm 6.6$ & $\begin{array}{r}71.0 \pm 4.1 \\
(5)\end{array}$ \\
\hline
\end{tabular}

( ) Cases $* \mathrm{P}<0.05$ 
時に比し栓球粘着率は $1 \%$, 第（XII+XI）因子， 線溶能は $5 \%$ 以下の危険率で有意に低下した。他 万, 栓球数は増加, 栓球第 3 囚子亡第V汭因子は低 下するも軽度であつた．Propを $0.5 \mathrm{mg} / \mathrm{ml}$ に増量 すると栓球数は有意 $(\mathrm{P}<0.05)$ に增加した. 栓 球粘着率，第 $(\mathrm{XII}+\mathrm{XI})$ 因子は $1 \%$ ，第证因子， 線溶能は $5 \%$ 以下の危険率ですべて有意に低下し たが, 栓球第 3 因子は変化しなかつた.

PA，Prop打の沶の $0.5 \mathrm{mg} / \mathrm{ml}$ 単独添加時の成績 (Table 6) では, P AKよりり 栓球数の増加, 栓 球粘着率, 線溶能の低下が，Propにより栓球数の 増加，栓球第 3 因子，第（XII+XI）因子の上昇 が示された。しかしこれらの変化はP Aによる栓 球粘着率, Propによる栓球数以外有意差がなかつ た。

以上，in vitrok拉いてもAにより栓球数増加 を除いては凝固線溶能が元進するという成績を得 た.そしてPA $0.5 \mathrm{mg} / \mathrm{ml}$ はすべての因子に揖い てかかるAの作用を抑制し，またProp $0.5 \mathrm{mg} / \mathrm{ml}$ はAの栓球第 3 因子活性のみは抑制できなかつた が，他の因子に対しては明らかに抑制した。

\section{IV. 総括ならびに考案}

C A の血液凝固能に及ぼす影響については，動 物実験でVosburgh (1903), Cannon (1914), Wa$\operatorname{kim}(1946)$ らが A による凝固時間または P T の短 縮をみたと報告している。 またヒトではForwell ら(1957)が A による凝固時間の短縮と第 $\mathrm{V}$ 因子活 性の上昇を確かめた。ささらに1961年Ingram ${ }^{7}$ が七 トにA 10〜16 $\mu \mathrm{g} / \mathrm{min}$ 10分静注して第证因子は 上昇し，同量のN Aおよびisopropylnoradrenaline $20 \sim 40 \mu \mathrm{g} / \mathrm{min} 10$ 分後ではその上昇はみられなか つたと述べている. また栓球にかんしてはMcClure (1965)，Rowsell(1966)らがいずれる動物実験 でAによる栓球数増加を報告したが，1967年Mi1ls, Schwartzらはin vitroでヒトの血液にA，NA を添加しAで栓球凝集能が著明に上䒜し，NAで はその上昇は軽度であると述べた。 また $\mathrm{Kral}^{6) ら}$ はA $0.1 \mu \mathrm{g} / \mathrm{kg} / \mathrm{min}$ 静注 $15 ， 30$ 分後に 第林因子と 栓球数の増加がみられたという。ひるが壳つて本
邦では，島本教授とその共同研究者が5)8，ヒト にA, N A ともに $0.1 \mu \mathrm{g} / \mathrm{kg}$ 静注し 5 分後に AK よるCa再加凝固時間， P T の短縮 おっび栓球数 の減少を報告しているにすぎない。

以上の実験では，C Aによる凝固能の六進傾向 は示されているが，多くはC A投与量が比較的大 量で，著者らの如き虚血性心疾患発生との関連の 有無を検討したものではない。また同時に各種凝 固因子を系統的に検索したものはきわめて少な W.

著者らは緒言で述べた如く，C A が凝固六進を 介して虚血性心疾患の発生に関与し，あるいは発 作の引き金としての一つの役割を果す可能性を検 討すべく，生理的微量のCAを投与するととも に, 別に標準運動負荷を行なつて，多数の㠜固因 子を同時に測定した.

その結果，NA投与で栓球数，栓球粘着率，第 II， V, VIII因子，A投与で栓球数，栓球粘着率， 第 II，VII，（XII+XI）.因子の活性上昇が著明であ り，また第V因子も上昇傾向を示した。このうち 栓球数にかんしては前述の $\mathrm{Kral}^{6)}$ ，第壮因子にか んしてはKral'1)，Ingram"らがAで同じ成績を述 べているが，Ingram7)はNAでは第林因子活性の 上昇はみられないという，著者らの成續では， 第林因子のみならず測定した因子活性の多くがN $\mathrm{A} ， \mathrm{~A}$ のいず机によつても共通して上昇すること を明らかにしたるのといるる。

運動負荷による凝固能の変化についての報告は 著者らの知る限りではきわめて少ない。このらら Iatridis9 らは傾斜したトレッドミルを時速 7 マイ ルで 6 分間負荷した実験で，第VIII，XII囚子の上昇 は明らかで，第II，V，VII，X因子の上昇は明 らかでなかつたと述べている。またFinkelら ${ }^{10) か ゙ ~}$ 18分間のサイクリングで栓球粘着率の上昇を, Cohenら（1968） 疲労するまでトレッドミルを 負荷した後に第V四因子の上昇をみたと報告してい る. 著者らはC A 投与時に上昇したと同程度の C A 血中濃度を認めるMaster二階段二重運動負荷を 行なつたが，栓球数，栓球粘着率の増加，第 $\mathrm{V}$, 
VIII（XII+XI） 因子の上昇が著明であり，第II， $(\mathrm{VII}+\mathrm{X})$ 因子はわずかに上昇傾向を示すことが 明らかとなつた。このうち栓球粘着率については Finkel ${ }^{10)}$ の，第訮因子についてはIatridis ${ }^{9)}$, Cohen らの成績と一致しているが，第 II，V因子につい てはIatridisのそれと異なる。その理由は明らか ではないが，一つは運動量の相違によるものと思 われる．とすあれ著者らの運動条件での血中レベ ルはC A投与時のそれとほぼ同じであり，両実験 での成績がほとんど一致したことはきわめて興味 深いものがある.

つぎに，P T T, 血浆因子は N A，A運動負荷 いずれに和いても前者の短縮，後者の活性上昇が 著明であつた。これに対してP T，血清因子の変 化はN Aのみで有意であつたが A，運動負荷では 明らかでない。

線溶能にかんしては C A, 運動負荷で線溶能が 穴進することは，1947年Biggsら ${ }^{11)}$ とる E L T の短縮の報告にはじまる．その後Sherryら ${ }^{12)}$, Genton $5^{18)}$ ，松村 ${ }^{14)}$, Cash $5^{15)}$ その他は, C A 負 荷後の E L T 短縮, Kral $5^{6)}$ は線溶fibrin溶解能の

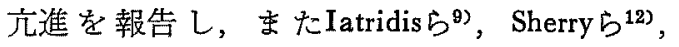
Cash ${ }^{15) 18)}$, Mennon ${ }^{17)}$ その他は運動負荷後の E L T 短縮を報告している. 著者らの成績では, N A，A，運動負荷いずれにおいてもE L T 短縮 は明らかであり，諸家の成績と一致するもので ある。またfibrinogen量に变化をみなかつた点る Iatridis $^{92}$, Cash $^{16)}$ らの成績と一致する.

以上の成績を総括すると，NA負荷による凝固 能充進は P T T の短縮，血浆因子之第VII⿴囗大因活性 の上昇，A，運動負荷ではこれに加えて第（XII十 XI）因子活性上昇も著明であることから，C A に よる凝固能六進は内因性凝固因子の六進之栓球の 関与が大であることが結論つけられる。また線溶 能では E L Tが短縮しfibrinogen量は著変なかつ た。すなわち線溶活性が C A，運動負荷によつ て明らかに六進することを認めたといえよう。 fibrinogen量が 著変なかつたのは，採血時間に問 題があるか，あるいは線溶活性度の增加が相対的 に低く，fibrinogen量に著明な影響を与えること が少なかつた故かも知れない。

C Aの血行動態および代謝面に対する効果を考 える場合，交感神経受容体の面を無視することは できない，同じ観点からC Aの凝固線溶能に及渒 す影響についてす遮断薬を用いて受容体の面から 解明しようとした研究は後に述べる如く少なくな い. 著者らもC AKよる凝固線溶能六進の機序の 一部を解明する目的で，前述の実験でとくに六進 の著しからた凝固因子を選び，C A のこの作用に 対する遮断薬の影響についてまずin vivoで検討し た.しかしin vivoでは栓球凝集能の充進と第VIII， XII因子が相互に関連しあって凝固亢進をるたらす こと，同時にCAKよる血行動態，ならびに脂質 や糖質の代謝等への影響が血液凝固に反映するこ とが考えられるので，in vitroの実験むあわせ施 行した.

まずin vivoでは，対照として行なつたA単独負 荷でいずれの因子す上昇あるいは增加し，それは 栓球第 3 因子を除いてはすべて有意であり，前穾 験成績と同じく凝固線溶能の明らかな亢進が示さ れた.これに対してPAは，Aによるこれら諸因 子の充進をすべて明らかに抑制し，第怔因子を除 きすべて逆に前值より低下せしめた。このうち栓 球粘着率，栓球第 3 因子，第 (XII+XI) 因子の低 下はPA単独負荷ですでに出現し，これも影響し たと考觉られるが，少なくもAの作用は認められ ないまたPropはAKよる栓球粘着率，栓球第 3 因子，第VIII，（XII+XI）因子，線溶能の六進を明 らかに抑制し，第䜣因子を除きすべて逆に前值よ り低下せしめた。 これら諸因子の低下はProp単独 負荷ですでに出現し，これす影響したと考えられ る.

つぎにin vitroでは，A10 $\mu$ g添加時，栓球数の 減少，栓球粘着率，栓球第 3 因子，第 (XII+XI) 因子, 線溶能活性の著明な増加, 第怔因子の増加 傾向がみられた。これに対してP A $0.5 \mathrm{mg}$ 栓球 数をむしろ增加させ，他の因子はすべてAによる 活性上昇を抑制して，栓球数を除いてはin vivoの 
成績とほぼ一致したささらにProp $0.5 \mathrm{mg}$ む栓球第 3 因子を除きP A と同様の成績を示した. 栓球数 の增加はPA, Prop 0.5mg単独添加時にすでみら れたが，栓球が薬物を加える以前にすでにわずか ながらの㠜集がみらら，これは栓球内の $\mathrm{C} \mathrm{A}$ 等の 放出によることは容易に想像される。これがPA， Prop添加で解離し結果として栓球数の増加となつ たものと思われる。

さて，さきにin vivoに招ける $\mathrm{C} \mathrm{A}$ の凝固能京進 作用は栓球就よび第VIII，（XII+XI）因子を介寸る のではないかと述べた． in vitroに乹いても，栓 球粘着率，第VIII，(XII+XI）因子打よび線溶能立 進が示されたことは，第VIII，（XII+XI）因子, 線 溶能測定に用いた血浆が P P P であり，栓球の関 与を受けていないと想定されるので，CAがこれ ら凝固因子に直接作用していると考克られ興味潹 い.ところで第XII因子は異物面，カオリン，七ラ イト等により活性化されることはよく知られてい るが，Ratnoffら ${ }^{18}$ は，o-dihydroxyl化合物が第XII 因子を直接活性化することから，この活性化は o-dihydroxyl基によるものであろうと推定した.

この推定に従えば，C A む同様にo-dihydroxyl化 合物であるから，C A が直接第XII因子に作用して 活性化をるたらす可能性は十分考兄られよう.

ここでCAの凝固能六進を交感神経受容体の 面からみるに，栓球については，C A は栓球内の adenylcyclaseを 抑制 してATPase活性を上昇させ るように働くとSalzmanら ${ }^{201} は$ 述べて物り，もし そらであるならば $\beta$ よも $\alpha$ の方が優位であるよ らに思われる。事実McClureら 数增加, Mills (1967), Schwartz (1967) らは同 じくAによる栓球凝集能儿進が P A で抑制された と述へ，Kralら ${ }^{6)}$ は栓球数の増加は $\beta$ 遮断薬で抑 制されなかつたと述べている．著者らのin vivoの 実験です栓球数の増加はP Aで抑制されたがProp では抑制されないといら成績を得た．以上より少 くとも栓球数の増加は $\alpha$ 作用にもとづく面が多い ことが推定される.ただMcClureら゙は粘着栓球 数の増加はPropにより抑制されると述べており，
また著者らの成績で，栓球粘着率扣よび第 3 因子 活性の上昇が両遮断楽で完全に抑制されたので, これらが $\alpha$ 作用によるといらにはまだ問題が残る であろう．ただこの栓球粘着率, 第 3 因子活性は 少なくひin vivoの実験 ではPA，Prop単独投与で すでに低下したことから，果して両遮断薬のC A 拮抗作用をみているか否か题問であるといえよ 5 .

つぎに第VII⿴囗大决，Ingramら"はAの第 VII因子上昇はP A では阻止されず，Propおょよび pronethalolで阻止されることから，Aの作用は $\beta$ 作用によるるのであるとし，他方Özgeら ${ }^{19}$ はA の第䜣因子活性上昇はphenoxybenzamine で阻止 されたと報告しており， $\alpha, \beta$ 受容体のいずれが関 与するか今日まで結論㥂られないようである。 著者らの成績では，他の多くの因子とともに $\alpha, \beta$ 両遮断薬が $\mathrm{CA}$ の作用を阻害することを明らかに した. Ingramは著者らとほぼ同量のP A を用い てその阻害作用を否定しているが，これは彼の実 験ではAの量が著者らのそれの約 1.5倍と大量で あること，つまりこのA 量に対してPA量が比較 的に少なかつた故ではあるまいか。

次に第（XII+XI）因子は前述のRatnoffの成績 のようにC Aの直接作用を受ける可能性が大で, したがって他の因子以上に交感神経受容体と結び つけた研究は興味がある。しかし調查し得た限り ではこの因子を検討した報告はみられない，著者 らの成績ではAによる第（XII+XI）因子の活性上 昇が両遮断薬で阻害されておらり， $\alpha, \beta$ 受容体に特 異的にAが作用するか否か問題であるう.

$\mathrm{A}$ の線溶能元進が種々の $\beta$ 遮断薬で阻止される

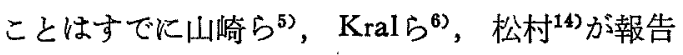
している，一方，著者らの成績では及のみならず $\alpha$ 遮断薬によつてるその克進は抑制された。その 違いの理由の一つとて, 山崎, 松村らが使用し たAの量および $\alpha$ 遮断薬の使用方法とその量的相 異によるものであろう。なお Kralは $\alpha$ 遮断薬の影 響については検討していない。

最後に本実験の成績に基づきP A と Propとの作 
用を比較すると，P A とよる抑制効果は栓球数特 よび栓球第 3 因子に対してはPropによるそれより も一層強力であつた．また栓球粘着率と線溶能に 対してはPropの方が逆にPAより強く，第林，

(XII+XI) 因子に対しては同程度であつた。 以上 の如く因子によつてはPA，Propの効果はまちまち でありいずれがより強力であるとは断言し難い が，ともにC A の㠜固線溶能進作用を抑制する ことは確実とい党よう。

以上C A の㠜固能元進栓球，第XII因子に対 L 直接的に作用するすので，乙かもこの作用は生理 的微量のCAでも認められることを明らかにし た。

動脈硬化症に括ける血栓症の成立には，凝固能 交進がその一因として関与していると考えられる が，ストレスによりC Aの体内放出がみられるこ と，また虚血性心疾患と各種ストレスないしは近 代生活様式との深い関連性を考劣る時，C A 方 する凝固能九准を本症の発生すしくは促進因子の 一つと考えることは，必ずしも諭理の飛躍とはい えまい，とくに狭心症発作時にみられるとほぼ同 じ血中C A 増量によつて凝固能の亢進すること は, いわゆるimpending myocardial infarctionの 成立機序の一つと考えることが可能であるう。他 方 C A は冠動脈硬化症に打いて，その血行動態一 の影響によつて心筇が虚血状態に傾むくことが明 らかにされて括り゙，このCAの作用を抑制する $\alpha$ ならびに $\beta$ 遮断蝶が，いずれもC Aの血液凝固 能克進效果を抑制することはきわめて興味深い。

\section{V. 結 論}

虚血性心疾患の発生むしくは促進因子としての C Aの作用を，血液凝固線溶能に及ぼす影響から 検討すべく, N A $0.2, A \quad 0.1 \mu \mathrm{g} / \mathrm{kg} / \mathrm{min} の 10$ 分 間点滴ならびにMaster二階段二重運動負荷を行な い，その前後の㠜固線溶能について検討した。さ らKC A の㠜固線溶能に対する作用への $\alpha, \beta$ 遮断 薬の影響をin vivo，in vitroで検討した。そ誠 績は次の如くである.

1） C A 負荷
(1) N A 負荷 : 栓球数, 栓球粘着率の増加, P T , P T T , 第 II，V，江因子，血浆扣よび血 清因子，E L T の上昇または時間短縮は有意であ り，他方第 $(\mathrm{VII}+\mathrm{X}),(\mathrm{XII}+\mathrm{XI})$ 因子, fibrinogen 量は不变であつた。

(2) A 負荷 : 栓球数, 栓球粘着率の増加, P $\mathrm{T} \mathrm{T}$ ，第 II，VIII，（XII+XI）因子，血浆因子， E $\mathrm{L} T$ の上昇をたは時間短縮は有意であり，第 V因 子， P T, 血清因子は有意ではないが上昇または 時間短縮を示したが，第(VII $+X)$ 因子，fibrinogen 量は不変であった。

2）運動負荷：栓球数, 栓球粘着率の増加, P T T ，第 V，VIII（XII+XI）因子，血浆因子， $E$ L T の上昇をたは時間短縮は有意であり，第 II， (VII+X)因子，血清因子は軽度ながら上昇した。 他方PT, fibrinogen量は不変であつた。

3） C A と遮阯薬にかんする影響

(1)In vivo:（i）A単独負荷；栓球数，栓 球粘着率の増加，第VIII（XII+XI）因子，線溶能の 上昇は有意であり，栓球第 3 因子も有意ではない が強い上昇を示した。（ii） P A の影響；P A 単独では栓球第 3 因子の減少以外以著変なく, $\mathrm{P}$ $\mathrm{A}$ を $\mathrm{A}$ と同時に投与すると， $\mathrm{A}$ による上昇を $\mathrm{PA}$ はすべて抑制した. (iii) Propの影響； Prop単 独で栓球粘着率, 栓球第 3 因子活性の低下扝よび 栓球数の増加がみられたＡによる栓球数の増加 はpropにより抑制されなかったが他の因子はすべ て抑制された。

(2)In vitro: (i ) A $5 \mu \mathrm{g} / \mathrm{ml}$ 添加時, 線溶能 は有意に上昇した，栓球数は減少傾向，他の因子 は上昇傾向を示する有意ではなかつた。A $10 \mu \mathrm{g}$ 添 加では，栓球数の減少，栓球粘着率，栓球第 3 因 子，第 $(\mathrm{XII}+\mathrm{XI})$ 因子, 線溶能の上昇はすべて有 意であり，第V西因子る有意ではないが上昇した。

(ii) A $10 \mu \mathrm{g}$, PA $0.5 \mathrm{mg} / \mathrm{ml}$ 添加时, すべての 因子に対するAの変化が抑制された。（iii） A 10 $\mu \mathrm{g}$, Prop $0.5 \mathrm{mg} / \mathrm{ml}$ 添加時, $\mathrm{A}$ による栓球第 3 因 子のみは変化を受けなかつたが他の諸因子は抑制 された。 


\section{文献}

1) 宮原光夫, 飯村 攻：カテュールアミン，第 1 版，医学書院，東京，1968。一2) 小楖掌：狭心症 発作とカテコラミンに関する研究，柇棍医誌，38： 122 136, 1970. - 3) McClure, P.D., Ingram, G. I.C. and Vaughan Jones, R.: Platelet changes after adrenaline infusions with and without adrenaline blockers. Thromb. Diath. Haemorrh. 13: 136 139, 1965. -4) Ingram, G.I.C. and Vaughan Jones, R.: The rise in clotting factor VIII induced in man by adrenaline: Effect of $\alpha$ - and ß-blockers. J. Physiol. 187: 447 454, 1966.

5) Yamazaki, H., Sano, T., Odakura, T., Takeuchi, K., Matsumura, T., Hosaki, S. and Shimamoto, T.: Appearance of thrombogenic tendency induced by adrenaline and its prevention by $\beta$-adrenergic blocking agent, nialamide and pyridinolcarbamate. Thromb. Diath. Haemorrh. 26: 251 263, 1971. -6) Kral, J.G., Ablad, B., Johnsson, G. and Korsan-Bengtsen, K.: Effects of adrenaline and alprenolol (aptin) on blood coagulation and fibrinolysis in man. Europ. J. clin. Pharmacol. 3: $144 \sim 147,1971$. -7) Ingram, G. I.C.: Increase in antihaemophilic globulin activity following infusion of adrenaline. J. Physiol. 156: 217 224, 1961. - -8) 竹内邦夫 : 血栓予防 に関する研究一七トに括ける adrenaline 負荷，動 物脂肪負荷時における血液凝固性の亢進，および pyridinolcarbamate 予防奻果について一，お茶の 水医誌， $13 ： 225 \sim 232 ， 1965 .-9$ ) Iatridis, S. G. and Ferguson, J.H.: Effect of physical exercise on blood clotting and fibrinolysis. J. Appl. Physiol. 18: 337 344, 1963. -10) Finkel, A. and Cumming, G.R.: Effects of exercise in the cold and blood clotting and platelets. J. Appl. Physiol. 20: 423 424, 1965. -11) Biggs, R.,
Macfarlane, R.G. and Pilling, J.: Observations of fibrinolysis - Experimental activity produced by exercise or adrenaline-. Lancet 1: 402 405, 1947. -12) Sherry, S., Lindemeyer, R.I., Fletcher, A.P. and Alkjaersig, N.: Studies on enhanced fibrinolytic activity in man. J. clin. Invest. 38: 810 822, 1959. -13) Genton, E., Kern, F. and von Kaulla, K.: Fibrinolysis induced by pressor amines. Amer. J. Med. 31: 564 571, 1961. -14) 松村釣男：微量 adrenaline 静注時の線雓素 溶解現象元進とこれに対する adrenergic blocking agent，括よび pyridinolcarbamate 前処置の好果に 関する研究一線維菜溶解現象火関寸る研究第 1 報 一技茶の水医誌, $13: 233 \sim 240,1965$. -15) Cash, J.D. and Allan, A.G.E.: The fibrinolytic response to mderate exercise and intravenous adrenaline in the same subjects. Brit. J. Haemat. 13: 376 383, 1967. -16) Cash, J.D. and Woodfield, D.G.: Fibrinolytic response to moderate, exhaustive and prolonged exercise in normal subjects. Nature 215: 628 629, 1967. - 17) Menon, I.S., Burke, F.D., Smith, P.A., Newell, D.J. and Dewar, H.A.: A study of possible causes of increased fibrinolytic activity during exercise. Thromb. Diath. Haemorrh. 21: 287 292, 1969. -18) Ratnoff, O.D. and Crum, J.D.: Activation of Hageman factor by solutions of ellagic acid. J. Lab. clin. Med. 63: 359 377, 1964. -19) Özge, A.H., Rowsell, H.C., Downie, H.G. and Mustard, J.F.: The effect of adrenaline infusions on blood coagulation in normal and haemophilia $\mathbf{B}$ dogs. Thromb. Diath. Haemorrh. 15: 349 364, 1966. -20) Salzman, E.W. and Neri, L.L.: Cyclic 3',5'-adenosine monophosphate in human blood platelets. Nature 224: 609 610, 1969. 